doi: 10.47072/demiryolu.1018663

http://dergipark.org.tr/demiryolu

e-ISSN: 2687-2463, ISSN: 2149-1607

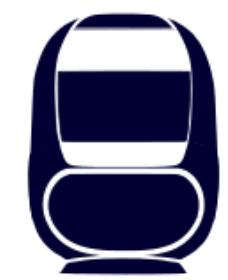

\title{
Design of a Metro Train and Structural Analysis of the Metro Vehicle Body by Finite Element Method
}

\author{
Muhammed Emin ARI*1(D, İsmail ESEN ${ }^{2}$ (D) \\ ${ }^{1}$ Karabük University, Institute of Graduate Programs / Mechanical Engineering, Karabük, Turkey \\ ${ }^{2}$ Karabük University, Engineering Faculty / Mechanical Engineering, Karabük, Turkey \\ *muhammedeminari@gmail.com
}

(Alınış/Received: 03.11.2021, Kabul/Accepted: 01.12.2021, Yayımlama/Published: 31.01.2022)

\begin{abstract}
Since metros are high capacity, fast and large in size compared to other urban rail vehicles, the importance of body strength is very critical. In this study, a four-car metro system was designed and structural analyses of the vehicle body were carried out using the finite element method according to EN 12663-1 standard. Structural analyses were performed under three different conditions. the total mass of the $22.7 \mathrm{~m}$ long vehicle with all its equipment was $35000 \mathrm{~kg}$, and the total passenger mass was calculated as $27020 \mathrm{~kg}$ based on the presence of 8 passengers per square meter, and the total total mass was taken as $62020 \mathrm{~kg}$. Various sizes of SUS304 stainless steel profiles and sheet materials have been selected for the body carrier skeleton system of the vehicle. In the analysis; vertical loads were made on the passenger side of the vehicle body and horizontal compression loads were made on the bumper areas and maximum stress and displacement amounts were determined. It was found that in the passenger compartment of the car body, the maximum amount of stress in vertical loads is below the yield stress, but in the case of compression loading in the bumper area, the maximum stress is above the yield stress. In order to provide the necessary stress conditions for the design of the buffer zone and its surroundings, solution proposals have been made to revise the design.
\end{abstract}

Keywords: Metro train, Urban rail system, Computer aided design (CAD), Finite element analysis (FEA), Structural analysis, Static-strength analysis

\section{Bir Metro Treni Tasarımı ve Metro Araç Gövdesinin Sonlu Elemanlar Yöntemiyle Yapısal Analizi}

Öz: Metrolar, diğer kent içi raylı araçlara göre yüksek kapasiteli, hızlı ve büyük boyutlu oldukları için gövde dayanımlarının önemi oldukça kritiktir. Bu çalışmada dört vagondan oluşan bir metro sistemi tasarlanmış ve araç gövdesinin EN 12663-1 standardına göre sonlu elemanlar yöntemiyle yapısal analizleri yapılmıştır. Yapısal analizler üç farklı koşulda incelenmiştir. 22,7 m uzunluğundaki aracın, tüm ekipmanlariyla birlikte toplam kütlesi $35000 \mathrm{~kg}$, metre karede 8 yolcu bulunma durumuna göre toplam yolcu kütlesi $27020 \mathrm{~kg}$ hesaplanarak genel kütlenin toplamı $62020 \mathrm{~kg}$ olarak alınmıştır. Aracın gövde taşıyıcı iskelet sistemi için değişik boyutlardaki SUS304 paslanmaz çelik profil ve sac malzemeler seçilmiştir. Analizde; araç gövdesinin yolcu bölümüne dikey yüklemeler, tampon bölgelerine de yatay olarak sıkıştırma yüklemeleri yapılarak maksimum gerilme ve yer değiştirme miktarları tespit edilmiştir. Araç gövdesinin yolcu bölümünde, dikey yüklemelerdeki maksimum gerilme miktarının akma gerilmesinin altında olduğu ancak tampon bölgesindeki sıkıştırma yüklemesi durumunda maksimum gerilmenin akma gerilmesinin üzerinde olduğu tespit edilmiştir. Tampon bölgesi ve çevresinin tasarımında gereken gerilme şartlarını sağlamak amacıyla tasarımın revize edilmesi için çözüm önerilerinde bulunulmuştur.

Anahtar Kelimeler: Metro treni, Kent içi raylı sistem, Bilgisayar destekli tasarım (BDT), Sonlu elemanlar analizi (SEA), Yapısal analiz, Statik-mukavemet analizi

\section{Introduction}

There are many factors such as passenger volumes, topography, climate, station spacing, economy and vehicle aesthetics that are decisive in the creation of rail system vehicle designs 
[1], [2]. But the most fundamental factor in vehicle design is passenger volume. The amount of population in the cities and the size of this population's need for rail vehicles determine the type of vehicle to be preferred its carrying capacity and thus the body size. Adopting the understanding of modern urbanism in cities, city administrations prefer the rail system, which is efficient, fast, comfortable and economical transportation [3]. The most advanced mode of urban rail systems is metro transportation. Metro transportation is very preferred in crowded cities due to its fast, reliable, comfortable and high passenger capacity [4]. Metros are urban rail system vehicles that are mostly operated in underground tunnels, but can also operate on the ground when necessary, and are fully protected thanks to their signalling systems [5], [6]. The high importance of human influence in metro systems highlights the safety factor in vehicles. Therefore, vehicle body designs should be at a level to provide body strength conditions that will allow the maximum capacity of passenger density to be carried and to meet the need for intensive passenger transportation for many years.

Factors such as the number of wagons, seating capacities, body sizes, and number of passenger doors in metro systems vary according to the limits required by cities in vehicle capacities. In this study, a metro system consisting of four wagons and four passenger doors on the right and left of each wagon, a total of eight passenger doors, is designed. The length of the wagons at the front and rear ends is $22.7 \mathrm{~m}$, and the length of each of the two wagons in the intermediate zone is $21.583 \mathrm{~m}$. The total seating capacity of this four-car system is 202 people. The passenger capacity that can travel standing is 1044 people in total, according to the density of 6 passengers per square meter, and the total number of standing and seated passengers is 1246 people. The optimum number of standing passengers per square meter in metro vehicles is 6 people. However, since higher strength was aimed in the analysis conditions, the number of passengers per square meter was kept at the maximum level and 8 people were accepted and static strength analysis of the vehicle body was made under these conditions.

Kim et al. examined and carried out studies on a train body made of composite material, adhering to the operating conditions of the train. Kim et al. studied the vertical collapses and cross-sectional deformations with the help of finite element method (FEM) [7]. Kim and Jeong investigated the natural frequency analysis of the train body using the finite element method in their study on a $23 \mathrm{~m}$ long aluminium core carbon epoxy surface, composite structure Korean tilt train. As a result, Kim and Jeong compared the results of the obtained data with the measured data [8]. Kotil et al. investigated the static structural behaviour of a light metro vehicle using the finite element method [9]. Wu et al. have worked on subway collision animation based on ANSYS data and determined the deformations of the train body in the collision area [10]. Nas et al. carried out the structural designs of a light metro vehicle [11]. Küçükcicibıyık et al. examined the structural analysis of a light rail vehicle body using the finite element method and determined the stresses and displacements in the body [12]. In this study, the metros, which are the highest-capacity public transportation vehicles of urban rail transportation, are emphasized. The importance of body strength is very critical, as metros are faster, have more passenger carrying capacity and are larger in size compared to other urban rail transportation modes. The main purpose of this study is to determine the stresses and displacement amounts by examining the body strength of a sample metro vehicle under the required loading and operating conditions.

The structural designs of railway vehicle bodies depend on the loads to which they are subjected and the material properties of the body. The EN 12663-1 standard, which defines the structural requirements of railway vehicle bodies, has emerged to ensure that the structural designs in vehicle bodies are uniform. In the system designed within the scope of this study, the most critical metro vehicle in terms of loading conditions and design parameters was determined, and the created computer aided design (CAD) model is analysed in a computer environment with the finite element method according to the conditions in the EN 12663-1 standard. The 2018 
version of SOLIDWORKS commercial software was used in the design process. ANSYS Workbench commercial software version 18.1 was used for finite element analysis. The stresses and displacement amounts formed at the end of the analysis are examined and interpreted.

\section{Method}

Rail system vehicles are products with high-tech equipment, containing tens of thousands of parts and dozens of systems. There are over 100000 parts in a train set consisting of four metro cars, including only the smallest parts such as screws, nuts, etc. in various areas on the body. Traction, brake, air conditioning, auxiliary power, battery, door, passenger information, etc. in each metro vehicle. There are about 20 subsystems. Each system consists of many equipment and parts within itself. Each of the vehicles has approximately $10-15 \mathrm{~km}$ of cable length and about 8000-10000 cable connection ends, hundreds of meters of hydraulic system and pneumatic system piping installations. Therefore, rail system vehicles are complex systems, and the designs and production of vehicles should be carried out with disciplined approaches, adhering to international standards [13]. The design process created within the scope of this study, the determination of the technical data of the design, the finite element analysis and the loading conditions of the analysis are shown in Figure 1 step by step.

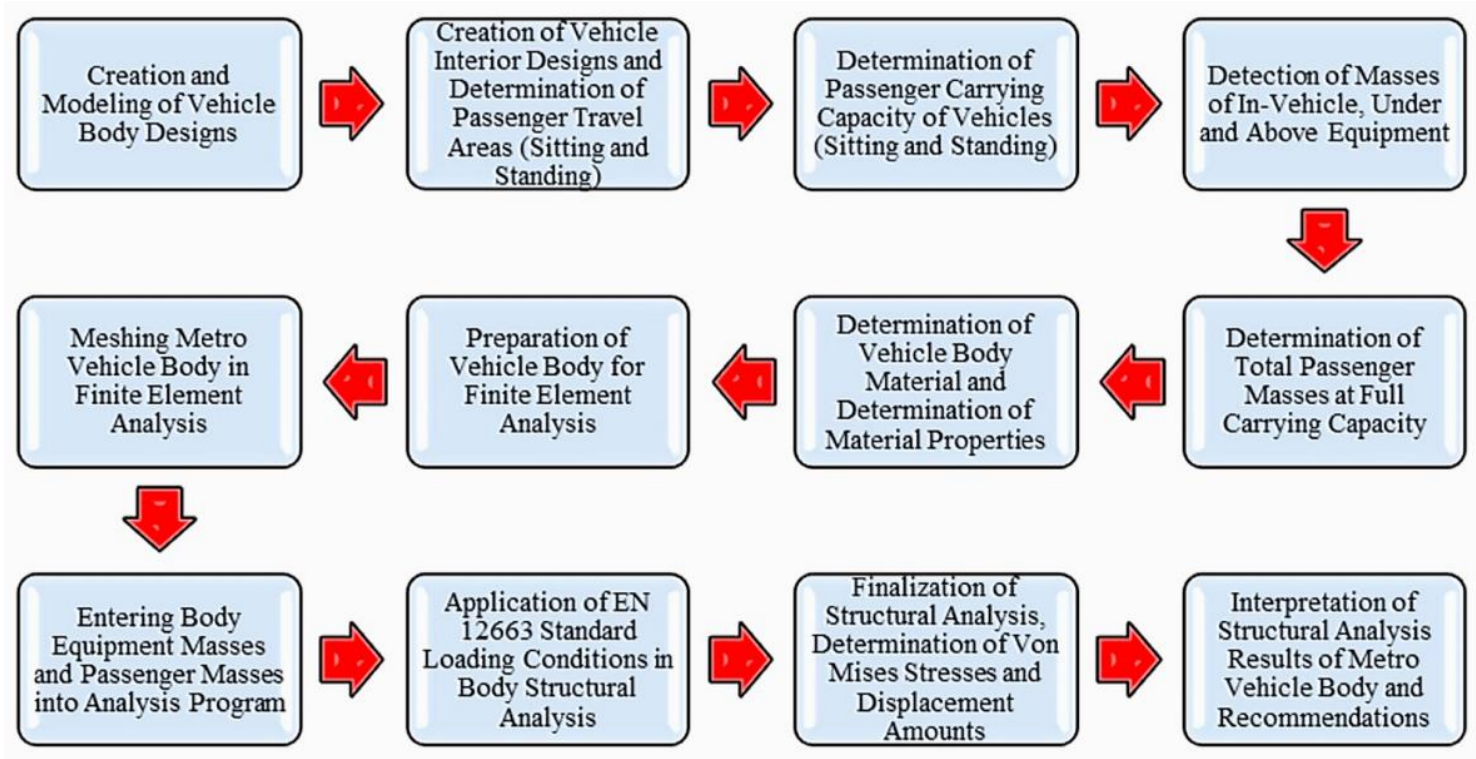

Figure 1. Design and analysis process

\subsection{Designs of vehicle models}

The design of the metro train set consists of four vehicles. These are MC1, T, M, and MC2 are vehicles. MC1 and MC2 are vehicles with propulsion systems located on both head parts of the train set. In other words, $\mathrm{MC}$ vehicles have a motorized bogie and driver's cabin. $\mathrm{T}$ and $\mathrm{M}$ vehicles represent the other two vehicles between the MC vehicles at the two ends of the set. The $\mathrm{M}$ vehicle is a vehicle with a motorized bogie but without a driver's cabin. T vehicle refers to a vehicle with a non-motorized bogie and no driver's cabin. The design of each of the metro vehicles was created using SOLIDWORKS commercial software. The general view of the vehicles in the metro set is shown in Figure 2. 


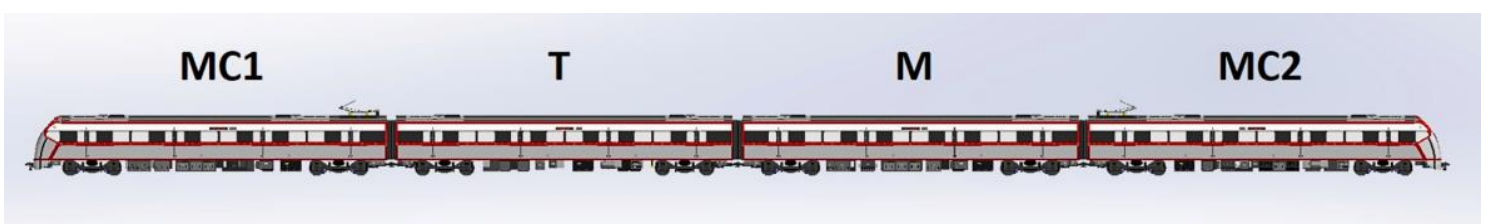

Figure 2. Vehicles in the metro set

The views and chassis of $\mathrm{MC} 1$ and $\mathrm{MC} 2$ vehicles and $\mathrm{T}$ and $\mathrm{M}$ vehicles are as in Figure 3.
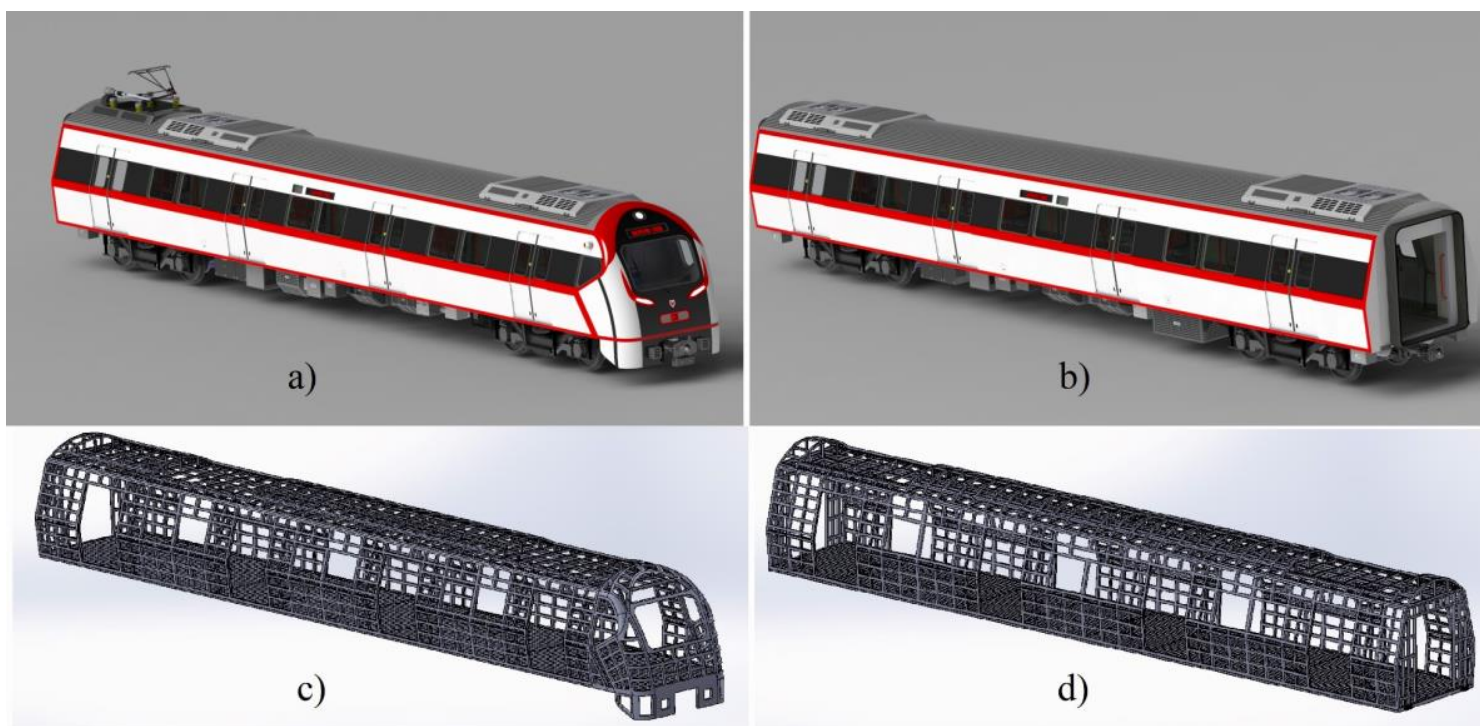

Figure 3. Metro vehicles and chassis a) MC vehicle b) M-T vehicle c) MC chassis d) M-T chassis

While designing metro vehicles, international standards and data obtained from literature research were adhered to. According to Vuchic's study, 90 vehicle models in different cities of the world were examined and based on the data obtained, the dimensions, capacities, weights and some performance data of tram, light rail, metro and suburban systems were determined. The data of the metro vehicles in this study by Vuchic are shown in Table 1 [1], [2].

Table 1. The data of a research conducted for the properties of metro vehicles [1], [2]

\begin{tabular}{lcccccccc}
\hline & $\begin{array}{c}\text { Vehicle } \\
\text { Length } \\
(\mathrm{mm})\end{array}$ & $\begin{array}{c}\text { Bogie } \\
\text { Range } \\
(\mathrm{mm})\end{array}$ & $\begin{array}{c}\text { Body } \\
\text { Width } \\
(\mathrm{mm})\end{array}$ & $\begin{array}{c}\text { Number } \\
\text { of Motor } \\
\text { Axles }\end{array}$ & $\begin{array}{c}\text { Number } \\
\text { of Doors } \\
\text { on One } \\
\text { Side }\end{array}$ & $\begin{array}{c}\text { Number } \\
\text { of Seats }\end{array}$ & $\begin{array}{c}\text { Total } \\
\text { Capacity }\end{array}$ & $\begin{array}{c}\text { Empty } \\
\text { Vehicle } \\
\text { Weight } \\
\text { (ton) }\end{array}$ \\
\hline Minimum & 14600 & 8200 & 2500 & 2 & 2 & 35 & 137 & 19 \\
Average & 18000 & 12000 & 2900 & 4 & 3 & 60 & 170 & 25 \\
Maximum & 22900 & 16500 & 3200 & 4 & 5 & 83 & 300 & 38 \\
\hline
\end{tabular}

The characteristics, dimensions, passenger carrying capacities and masses of each of the MC1, $\mathrm{T}, \mathrm{M}$ and $\mathrm{MC} 2$ vehicles in the four-car metro train designed within the scope of this study are shown in Table 2. 
Table 2. Metro vehicle features, dimensions, passenger capacities and masses

\begin{tabular}{lccccccccccc}
\hline Vehicles & \multicolumn{2}{c}{ Characteristics } & \multicolumn{4}{c}{ Dimensions $(\mathrm{mm})$} & \multicolumn{4}{c}{$\begin{array}{c}\text { Capacities } \\
\left(6 \text { passenger/m }{ }^{2}\right)\end{array}$} & $\begin{array}{c}\text { Mass } \\
\text { (ton) }\end{array}$ \\
\hline & Motor & Cabin & Width & Length & Height & $\begin{array}{c}\text { Bogie } \\
\text { Range }\end{array}$ & Sitting & Standing & Total & - \\
MC1 & Yes & Yes & 3185 & 22700 & 3725 & 15410 & 50 & 252 & 302 & 35 \\
T & No & No & 3185 & 21583 & 3725 & 14960 & 50 & 270 & 320 & 29 \\
M & Yes & No & 3185 & 21583 & 3725 & 14960 & 52 & 270 & 322 & 34 \\
MC2 & Yes & Yes & 3185 & 22700 & 3725 & 15410 & 50 & 252 & 302 & 35 \\
Total & & & & 88566 & & & 202 & 1044 & 1246 & 133 \\
\hline
\end{tabular}

As seen in Table 2, the vehicles with the largest dimensions and the highest mass are the MC vehicles. Therefore, in finite element analysis, the most critical vehicles are MC when considering the relevant loadings. Therefore, in this study, the results obtained by analysing the MC wagon are interpreted.

\subsection{EN 12663-1 Standard and vehicle body loading conditions}

Design and manufacturing criteria of rail system vehicle bodies; It is specified in the standard "EN 12663-1 - Railway Applications - Structural Requirements of Railway Vehicle Bodies" [14]. This European Standard; explains the rules to be considered regarding the structure of railway vehicle bodies. It describes the loads that vehicle bodies can carry and explains how to use material data where necessary. It explains the principles to be used in the control and verification of the vehicle body designs with the help of analysis and testing. Body structures in vehicle designs and load conditions applied to the body must meet the requirements of the relevant standard. The design masses to be used to indicate the vehicle load conditions according to the EN 12663-1 European Standard in the designs of railway vehicles are shown in Table 3.

Table 3. Definitions of rail system vehicle design masses [14]

\begin{tabular}{lcl}
\hline \multicolumn{1}{c}{ Definition } & Symbol & \multicolumn{1}{c}{ Description } \\
\hline $\begin{array}{l}\text { Design mass of the vehicle } \\
\text { body in working order }\end{array}$ & $\mathrm{m}_{1} \quad \begin{array}{l}\text { The design mass of the vehicle body in working } \\
\text { order according to EN } 15663 \text { without bogie masses. }\end{array}$ \\
$\begin{array}{lcl}\text { Design mass of one bogie or } \\
\text { running gear }\end{array}$ & $\mathrm{m}_{2}$ & $\begin{array}{l}\text { Mass of all equipment below and including the } \\
\text { body suspension. The mass of linking elements } \\
\text { between vehicle body and bogie or running gear is } \\
\text { apportioned between } \mathrm{m}_{1} \text { and } \mathrm{m}_{2} .\end{array}$ \\
$\begin{array}{l}\text { Normal design payload } \\
\mathrm{m}_{3}\end{array}$ & $\begin{array}{l}\text { The mass of the normal design payload as specified } \\
\text { in EN } 15663 .\end{array}$ \\
& $\mathrm{m}_{4}$ & $\begin{array}{l}\text { The mass of the exceptional payload as specified in } \\
\text { EN } 15663 .\end{array}$ \\
\hline
\end{tabular}

In the static-strength analyses of the designed metro vehicle body, three different loading scenarios are emphasized. The conditions for the loading scenarios in the static analysis are given in Table 4. 
Table 4. Loading conditions

\begin{tabular}{|c|c|c|c|}
\hline Condition & Load Status & Vertical Load & Horizontal Load \\
\hline 1 & $\begin{array}{l}\text { The biggest operating load } \\
\text { (vertical load) }\end{array}$ & $F_{z}=1.3 g\left(m_{1}+m_{4}\right)$ & - \\
\hline 2 & $\begin{array}{l}\text { Compression force in the buffer or } \\
\text { coupling area }\end{array}$ & $F_{z}=g m_{1}$ & $800 \mathrm{kN}$ \\
\hline 3 & $\begin{array}{l}\text { Vertical loads with compression force } \\
\text { in the buffer or coupling area }\end{array}$ & $F_{z}=g\left(m_{1}+m_{4}\right)$ & $800 \mathrm{kN}$ \\
\hline
\end{tabular}

The $g\left(\mathrm{~m} / \mathrm{s}^{2}\right)$ in Table 4 indicates the gravitational acceleration. The $m(\mathrm{~kg})$ values are the masses defined in Table 3.

In the loading scenario in Condition 1; 1.3 times the weight of the passengers is applied in addition to the weights of all the equipment in the body of the metro vehicle. This coefficient refers to the maximum working load of the metro vehicle in the EN 12663-1 standard.

In the loading scenario in Condition 2; a compressive force of $800 \mathrm{kN}$ is applied from the buffer or coupling area of the metro vehicle. This compression load; represents the resistance in the scenario of the vehicle being pushed by another vehicle.

In the loading scenario in Condition 3; in addition to all the equipment weights on the wagon body, the weights of the passengers and the $800 \mathrm{kN}$ compression load on the bumper or coupling area of the metro vehicle are applied together to analyse the strength of the vehicle body.

\subsection{Coordinate system}

In the coordinate system, the $\mathrm{X}$-axis corresponds to the longitudinal axis of the vehicle body. The direction of movement of the vehicle is the positive direction of the $\mathrm{X}$-axis. The positive direction of the Z-axis indicates the upward zone, and this is the vertical axis of the vehicle body. The Y-axis is the transverse axis of the vehicle body. So, the Y-axis is the lateral direction (Figure 4).

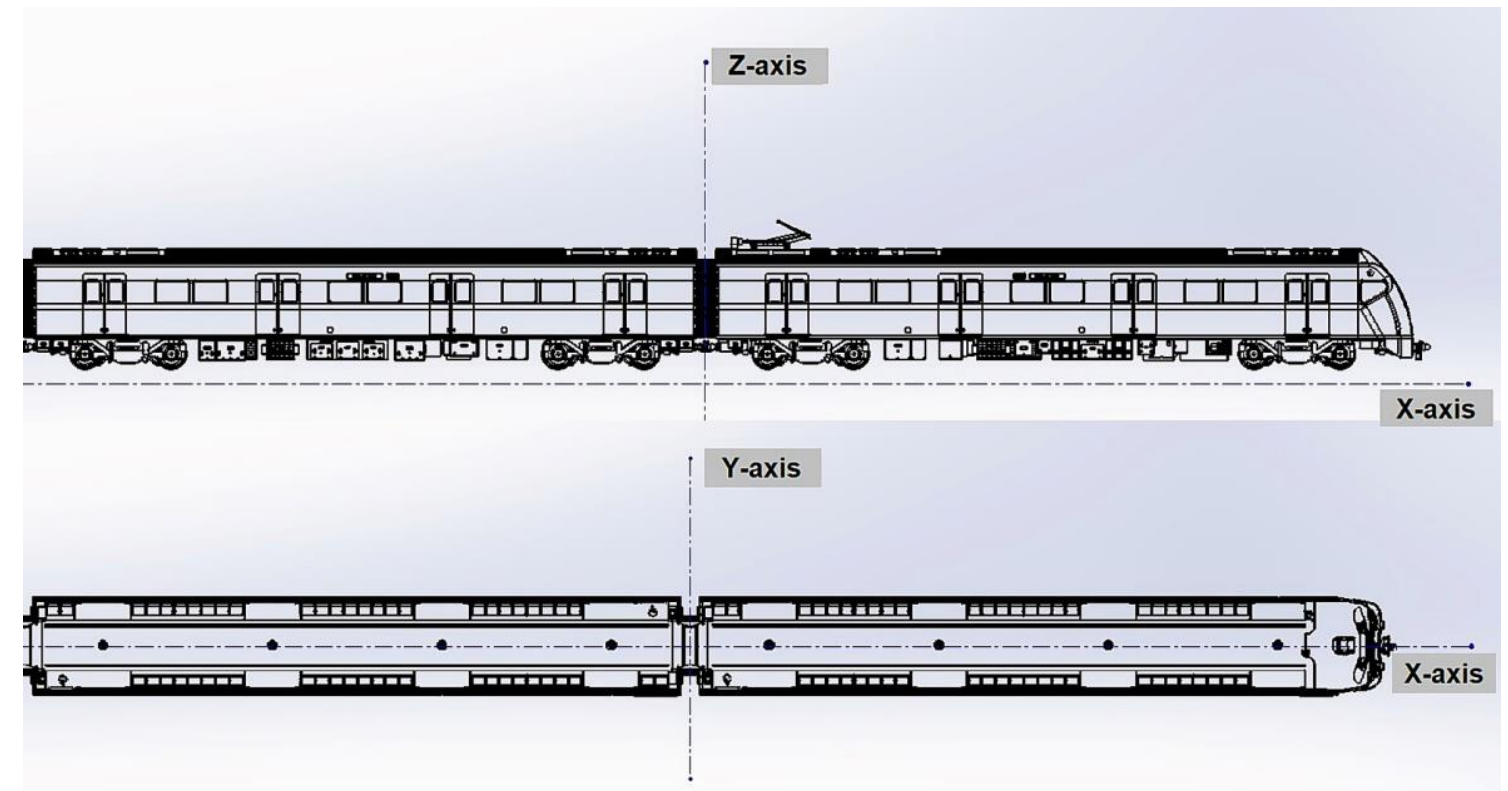

Figure 4. Metro vehicle coordinate system 


\subsection{Meshing process on vehicle body}

The meshing is done by using 4-node shell elements in the finite element mesh structure of the vehicle body. The body structure of the vehicle is generally formed as a result of combining thin sheet metal and beams. The thickness of the thin sheets in many parts of the vehicle body is much smaller than the geometric shapes of other parts. Therefore, it would be appropriate to use shell elements in the finite element analysis of the structural parts of the vehicle body [12]. The total number of elements obtained as a result of the mesh operation is 883796 and the total number of nodes is 1591640 (Figure 5).

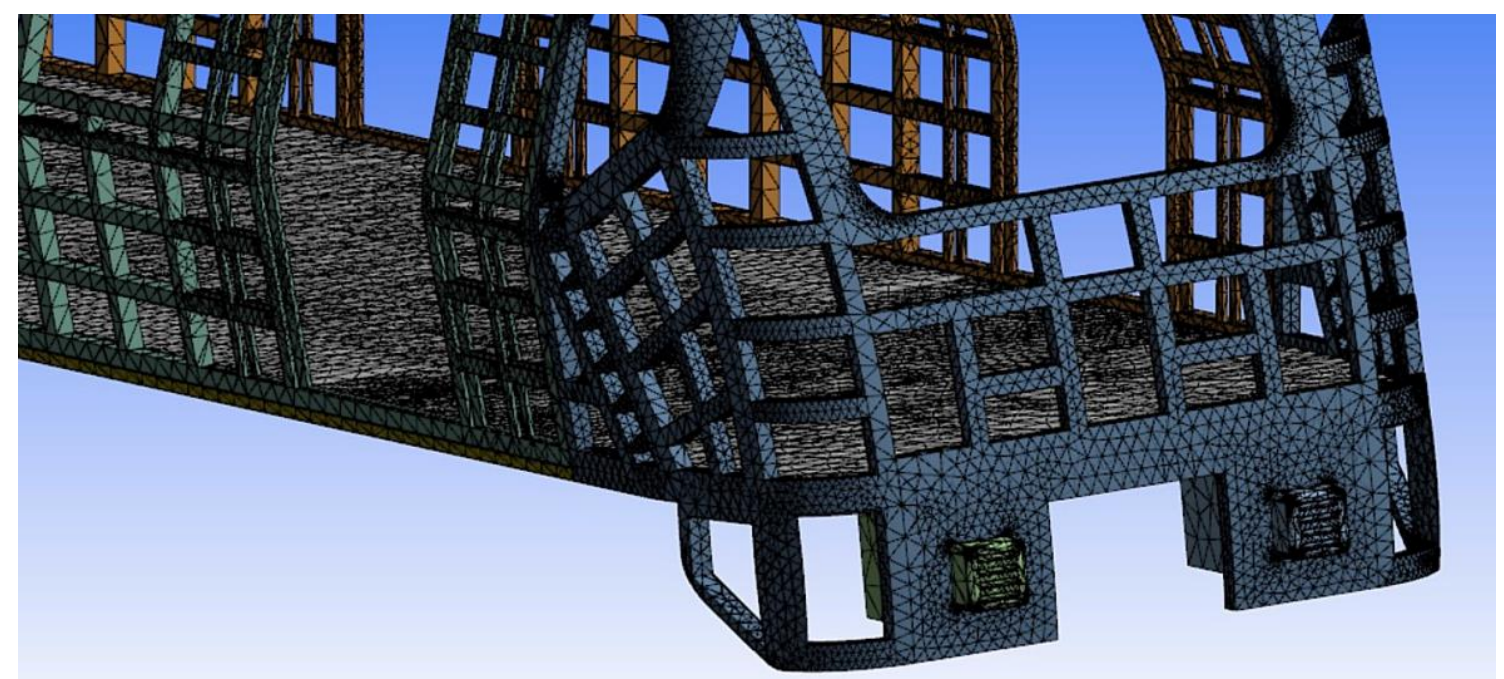

Figure 5. Mesh close-up

\subsection{Material}

SUS304 type high tensile strength stainless steel material is used in the body design of the metro vehicle. This material is highly resistant to corrosion. Weldability is very good, all welding methods except gas melt welding can be applied to SUS304 type stainless steel. 304 quality stainless steel, which is one of the most widely used steel materials in the world, is also highly preferred in the machinery and manufacturing industry. The use of rail system vehicles in body materials is also very common. The chemical composition of SUS304 stainless steel is shown in Table 5.

Table 5. The chemical composition of SUS304 stainless steel (\%) [15]

\begin{tabular}{|c|c|c|c|c|c|c|}
\hline $\mathrm{C}$ & $\mathrm{Mn}$ & $\mathrm{Si}$ & $\mathrm{P}$ & $S$ & $\mathrm{Cr}$ & $\mathrm{Ni}$ \\
\hline 0.08 & 2.00 & 1.00 & 0.040 & 0.03 & 18.00 & 8.00 \\
\hline Max. & Max. & Max. & Max. & Max. & $\begin{array}{c}\sim \\
20.00\end{array}$ & $\stackrel{\sim}{\sim 0.50}$ \\
\hline
\end{tabular}

304 quality stainless steel is also called as 1.4301 or X5CrNi18-10 according to EN norm. In the mechanical properties entered while defining the material for the vehicle body in the ANSYS Workbench program, the numerical values determined for the material $1.4301-\mathrm{X} 5 \mathrm{CrNi} 18-10$ from the material list in the SOLIDWORKS program are entered exactly. Table 6 shows the mechanical properties of SUS304 stainless steel material [16]. At the same time, values from the SOLIDWORKS program were added to the table. 
Table 6. Mechanical properties of SUS304 stainless steel material

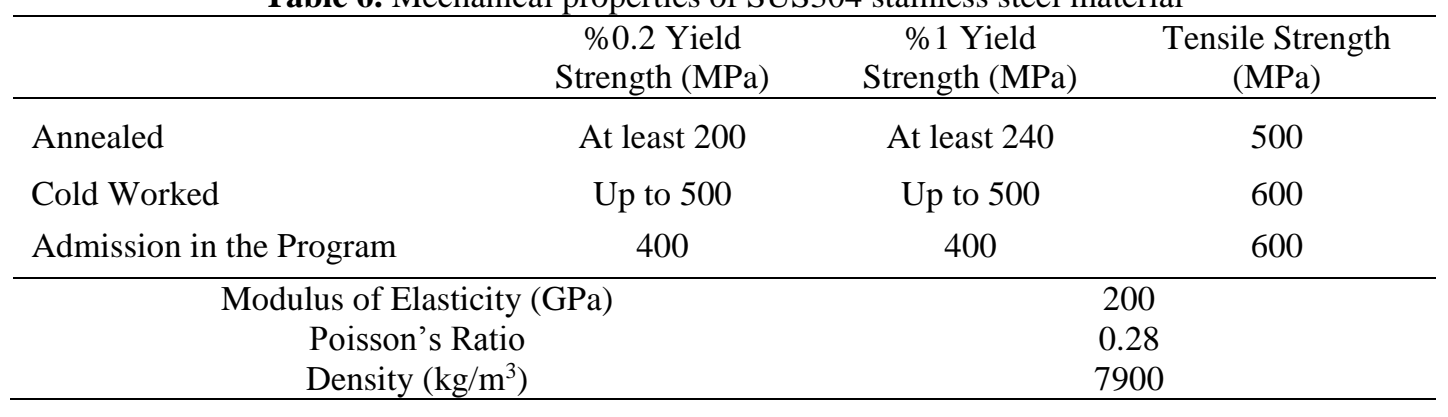

\subsection{Vehicle body skeleton mass}

In the $\mathrm{MC}$ vehicle in the metro set design, the skeleton (body) consist of the chassis floor, side walls, roof, rear panel, coupe, and pivot pad. The total mass of the skeleton with all these elements is $8150 \mathrm{~kg}$.

\subsection{Equipment masses}

In the chassis section of the metro vehicle, there are inverter, inverter auxiliary equipment, traction system auxiliary equipment, brake resistor unit, filter reactor, battery, auxiliary power unit, compressor, air tank, ATC, automatic coupling, and fixed coupling equipment. On the roof of the vehicle, there are two air conditioning units, as well as a pantograph and its equipment. The mass data obtained from the vehicles of the Metro Istanbul company are used as a reference for the equipment masses. The mass data of all this equipment, both on the roof and on the chassis floor, are given in Table 7 and the locations of the equipment in the vehicle are given in Figure 6.

Table 7. Vehicle equipment masses

\begin{tabular}{lccc}
\hline \multicolumn{1}{c}{ Equipments } & $\begin{array}{c}\text { Mass } \\
(\mathrm{kg}) \\
(\mathrm{m})\end{array}$ & $\begin{array}{c}\text { Actual Load }(\mathrm{N}) \\
\left(F_{z g}=m \times g^{*}\right)\end{array}$ & $\begin{array}{c}\text { Exceptional Load }(\mathrm{N}) \\
\left(F_{z i}=1.3 \times m \times g^{*}\right)\end{array}$ \\
\hline Air Condition 1 & 620 & 6082.2 & 7906.86 \\
Air Condition 2 & 620 & 6082.2 & 7906.86 \\
Pantograph & 250 & 2452.5 & 3188.25 \\
Inverter & 800 & 7848 & 10202.4 \\
Inverter Auxiliary Equipment & 260 & 2550.6 & 3315.78 \\
Traction System Auxiliary Equipment & 135 & 1324.35 & 1721.655 \\
Brake Resistor Unit & 285 & 2795.85 & 3634.605 \\
Filter Reactor & 500 & 4905 & 6376.5 \\
Battery & 250 & 2442.5 & 3188.25 \\
Auxiliary Power Unit & 1050 & 10300.5 & 13390.65 \\
ATC & 50 & 490.5 & 637.65 \\
Compressor & 250 & 2452.5 & 3188.25 \\
Air Tank & 25 & 245.25 & 318.825 \\
Automatic Coupling & 550 & 5395.5 & 7014.15 \\
Fixed Coupling & 210 & 2060.1 & 2678.13 \\
$g^{*}$ : gravitational acceleration $\left(\mathrm{m} / \mathrm{s}^{2}\right)$ & & & \\
\hline
\end{tabular}




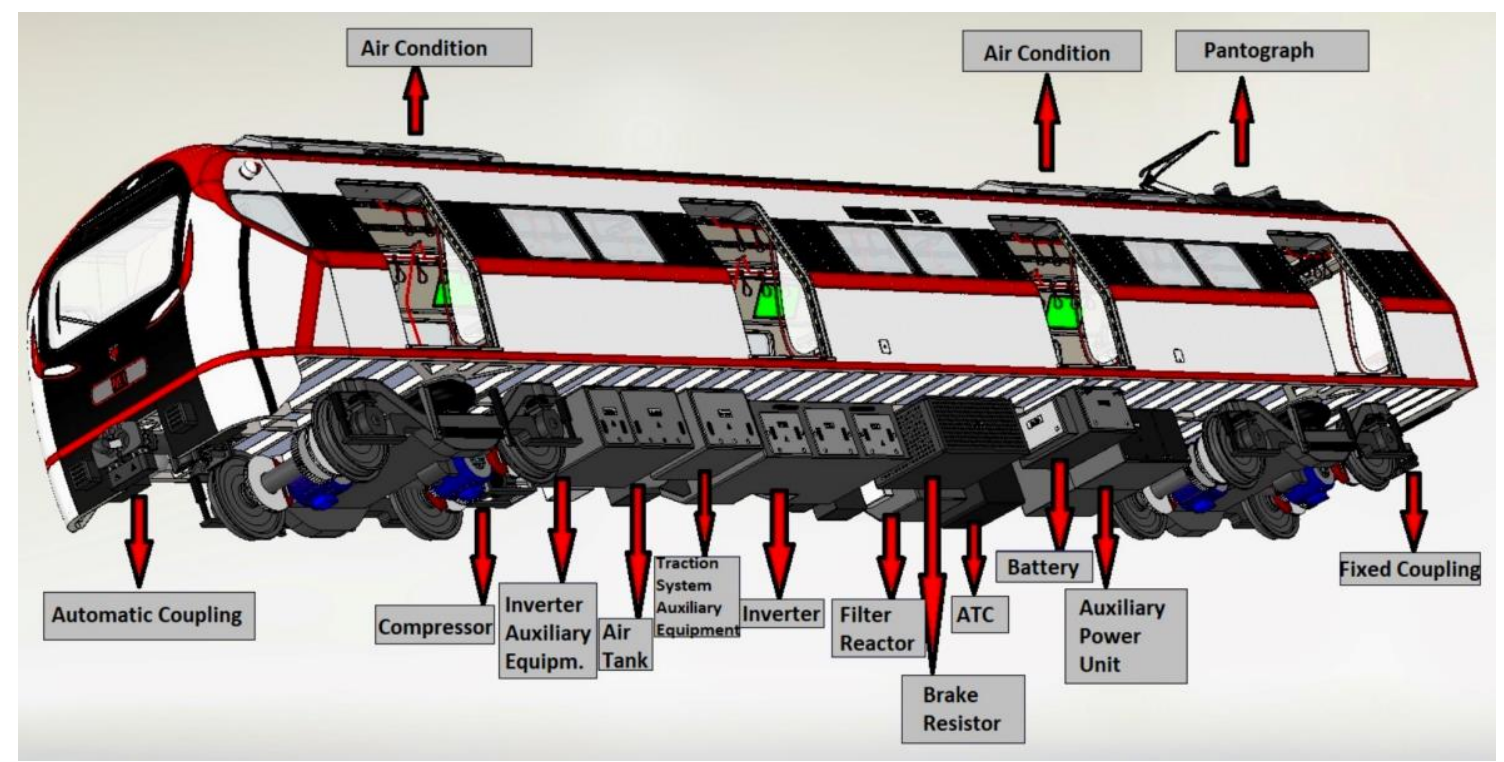

Figure 6. Under-vehicle and roof equipment

\subsection{Vehicle interior-exterior coating (trim) masses}

Floor coverings, passenger compartment glass panels, driver compartment glass panels, uprights, handrails, handles, passenger seats, driver's seat, vehicle driving panel, etc. were used in the interior of the metro vehicle. Elements are added to the relevant parts as a mass. In addition, the masses of structures such as doors, windows, side wall panels, roof panels, cup panels were also included in the calculation.

\subsection{Passenger masses}

The loading conditions in the standard "EN 12663-1 - Railway Applications - Structural Properties of Railway Vehicle Bodies" have been taken as reference for the passenger masses in the vehicle. According to this standard, the mass of each passenger is $70 \mathrm{~kg}$. In addition, the driver mass is accepted as $80 \mathrm{~kg}$ as a standard requirement.

Each of the MC vehicles in the metro set has a total of 50 seats. Except for the seat areas, the size of the area where standing passengers can be accommodated is calculated as $42 \mathrm{~m}^{2}$. The maximum number of passengers that can travel standing is 8 passengers per square meter. The numerical values of the passenger mass created by looking at these data about passengers and vehicles are shown in Table 8.

Table 8. MC vehicle passenger masses and weights

\begin{tabular}{lcccc}
\hline & Passenger & $\begin{array}{c}\text { Mass } \\
(\mathrm{kg})(m)\end{array}$ & $\begin{array}{c}\text { Actual Load }(\mathrm{N}) \\
\left(F_{z g}=m \times g^{*}\right)\end{array}$ & $\begin{array}{c}\text { Exceptional Load (N) } \\
\left(F_{z i}=1.3 \times m \times g^{*}\right)\end{array}$ \\
\hline Sitting Passenger & 50 & 3500 & 34335 & 44635.5 \\
$\begin{array}{l}\text { Standing Passenger } \\
\left(8 \text { passenger } / \mathrm{m}^{2}\right)\end{array}$ & 336 & 23520 & 230731.2 & 299950.56 \\
$\begin{array}{l}\text { Total Passenger } \\
\left(42 \mathrm{~m}^{2}\right)\end{array}$ & 386 & 27020 & 265066.2 & 344586.06 \\
$g^{*}$ : gravitational acceleration $\left(\mathrm{m} / \mathrm{s}^{2}\right)$ & & & \\
\hline
\end{tabular}




\subsection{Static-strength analysis with finite element method}

Finite element analysis is carried out by applying the loading scenarios for all three conditions specified in Table 4 to the body of the MC vehicle in the metro set. While analysing the vehicle, the body is fixed from the bogie connection points and the equipment and passenger loads were added to the relevant places. Necessary loading conditions have been provided for the determination of displacement amounts and stresses on the created model.

Stress is the amount of load acting on a unit surface. There are basically two types of stress. These are normal stress $(\sigma)$ and shear stress $(\tau)$. If the stress vector affects perpendicular to the surface of the relevant section, it is called normal stress, if it affects horizontally to the surface of the relevant section, it is called shear stress. Sometimes only one or both of these stresses can be found on the part [17].

In some engineering calculations, stress states can be complex. It can be subjected to both normal and shear stresses in many directions. It is difficult to determine the strength values of the part or system that is subjected to this type of loading. Some theories have been developed to make the necessary strength calculations when exposed to combined stresses in this way. Von Mises theory is one of them.

Von Mises theory is used as the fracture theory of ductile materials. Von Mises equivalent stresses are generally considered when evaluating stress results in finite element analysis. If the maximum equivalent stress obtained as a result of the applied loads in the analysis is greater than the yield stress of the preferred material, it means that the material is permanently deformed. That is, the value of the Von Mises stress in the fracture criterion should be less than the value of the yield stress of the material [18].

General equation of Von Mises stress [19];

$$
\sigma_{v m}=\sqrt{\frac{1}{2}\left[\left(\sigma_{y}-\sigma_{z}\right)^{2}+\left(\sigma_{x}-\sigma_{z}\right)^{2}+\left(\sigma_{x}-\sigma_{y}\right)^{2}+6\left(\tau_{y z}^{2}+\tau_{x z}^{2}+\tau_{x y}^{2}\right)\right]}
$$

Equation of Von Mises stress in terms of principal stresses [19];

$$
\sigma_{v m}=\sqrt{\frac{1}{2}\left[\left(\sigma_{1}-\sigma_{2}\right)^{2}+\left(\sigma_{2}-\sigma_{3}\right)^{2}+\left(\sigma_{3}-\sigma_{1}\right)^{2}\right]}
$$

Isotropic materials are materials that give the same response to thermal or mechanical loads in all directions. If the object returns to its original state when the loads are removed, this material has elasticity. According to Hooke's Law, there is a linear relationship between stress and strain. The most easily defined object in the finite element method is isotropic and linear elastic material. The stress-strain matrix [20];

$$
\left\{\begin{array}{l}
\varepsilon_{11} \\
\varepsilon_{22} \\
\varepsilon_{33} \\
\gamma_{12} \\
\gamma_{13} \\
\gamma_{23}
\end{array}\right\}=\left[\begin{array}{cccccc}
1 / E & -v / E & -v / E & 0 & 0 & 0 \\
-v / E & 1 / E & -v / E & 0 & 0 & 0 \\
-v / E & -v / E & 1 / E & 0 & 0 & 0 \\
0 & 0 & 0 & 1 / G & 0 & 0 \\
0 & 0 & 0 & 0 & 1 / G & 0 \\
0 & 0 & 0 & 0 & 0 & 1 / G
\end{array}\right]\left\{\begin{array}{l}
\sigma_{11} \\
\sigma_{22} \\
\sigma_{33} \\
\sigma_{12} \\
\sigma_{13} \\
\sigma_{23}
\end{array}\right\}
$$


In this matrix, $\varepsilon$ denotes the displacements caused by longitudinal elongation, $\gamma$ is the displacements caused by downward displacement, $E$ is the modulus of elasticity, $v$ is the poisson's ratio, $G$ is the shear modulus, and $\sigma$ is the normal stresses.

After the completion of the finite element analysis process of the metro vehicle model in the computer environment, the displacement amounts and Von Mises stresses were determined and the results were interpreted.

\section{Results and Discussion}

\subsection{Analysis for largest operating load (Condition 1)}

As shown in Table 4, static strength analyses are performed by taking 1.3 times of all vertical loads in the analysis of the largest operating load.

As a result of the finite element analysis, the maximum Von Mises stress is found to be 295 MPa. The region of maximum Von Mises stress is located under the vehicle, close to the pivot pad of the rear bogie. The general distribution of stresses is as in Figure 7.

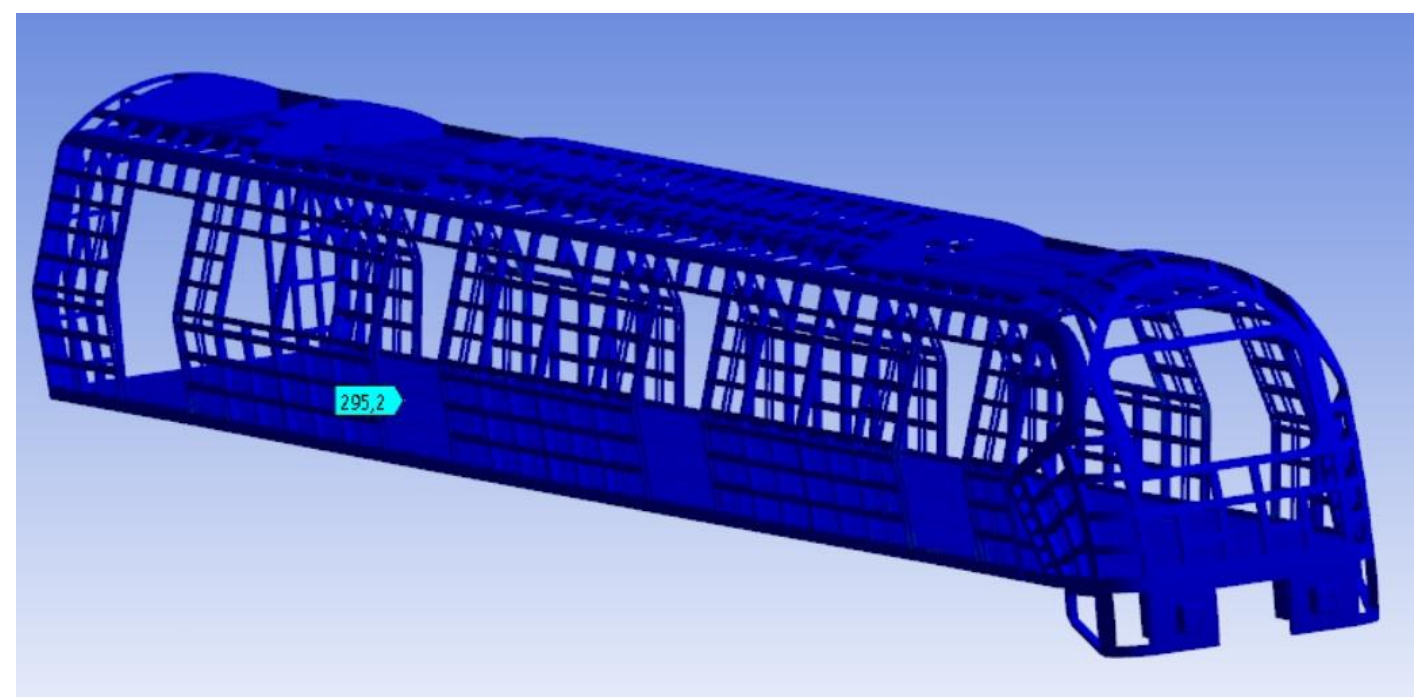

Figure 7. Von Mises stress distribution for condition-1

The yield strength of SUS304 stainless steel material is $400 \mathrm{MPa}$ as specified in Table 6 . In conclusion; The resulting maximum Von Mises stress value is $295 \mathrm{MPa}$, which is below the yield strength value of the material. According to the results obtained, the structure is safe for "Condition 1".

The displacement resulting from the static analysis is shown in Figure 8. The zone of maximum displacement is in the middle of the passenger compartment, with a maximum value of 18.86 $\mathrm{mm}$. 


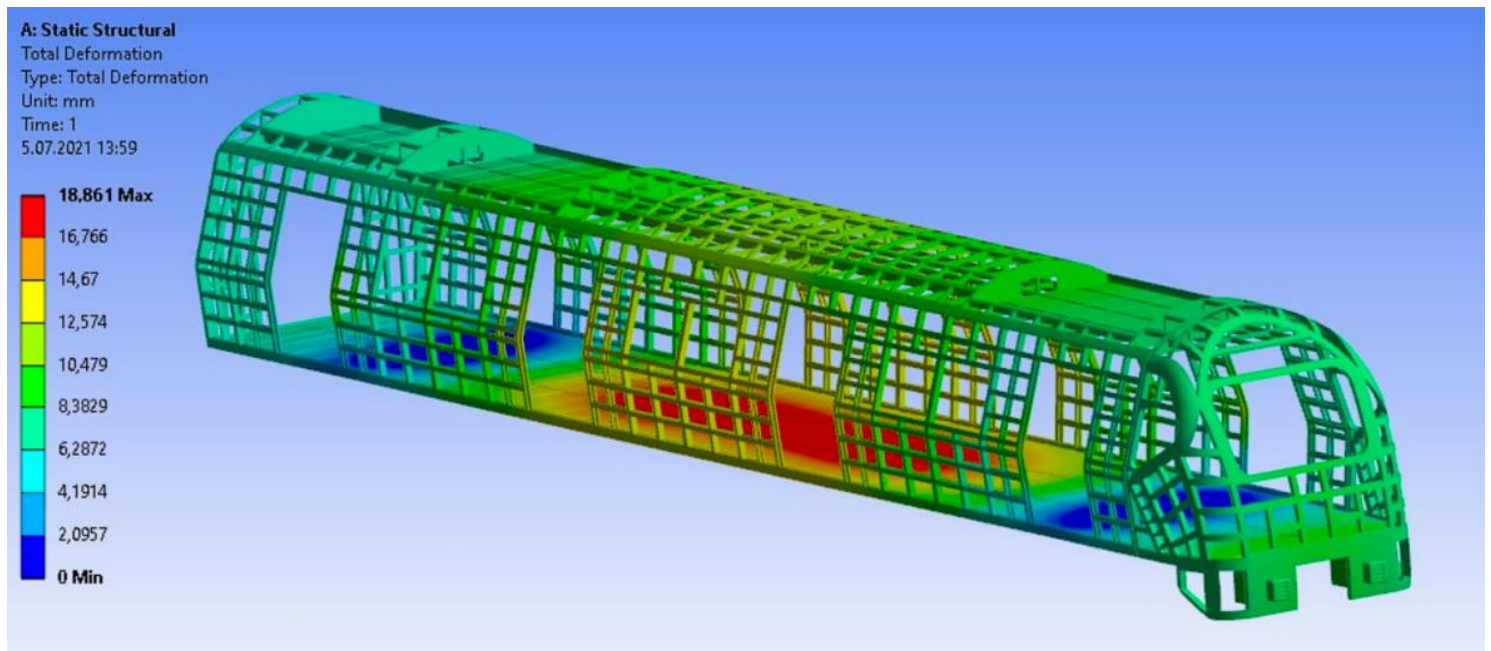

Figure 8. Maximum displacement for condition-1

\subsection{Analysis for application of compressive force in the buffer zone (Condition 2)}

There are no passengers in the vehicle under these analysis conditions. In addition, $800 \mathrm{kN}$ compression force is applied to the buffer zones together with the weights of the MC vehicle equipment. As a result of the static analysis, the maximum Von Mises stress is above $1600 \mathrm{MPa}$ in the periphery of the buffer zones and in the lower parts of the driver's cabin where the bumpers are mounted (Figure 9). This value is well above the $400 \mathrm{MPa}$ yield stress of the material in the design. Therefore, under the conditions of the EN 12663-1 standard, it is not safe against impacts or pressure forces from the buffer zone. This issue should be addressed with design improvements in the lower part of the driver's cabin. In addition, no spring mechanism system is used in the bumpers in the design. By using spring mechanisms inside the bumpers, it can be possible to reduce the deformation by absorbing the possible impact intensity to the bumper area.
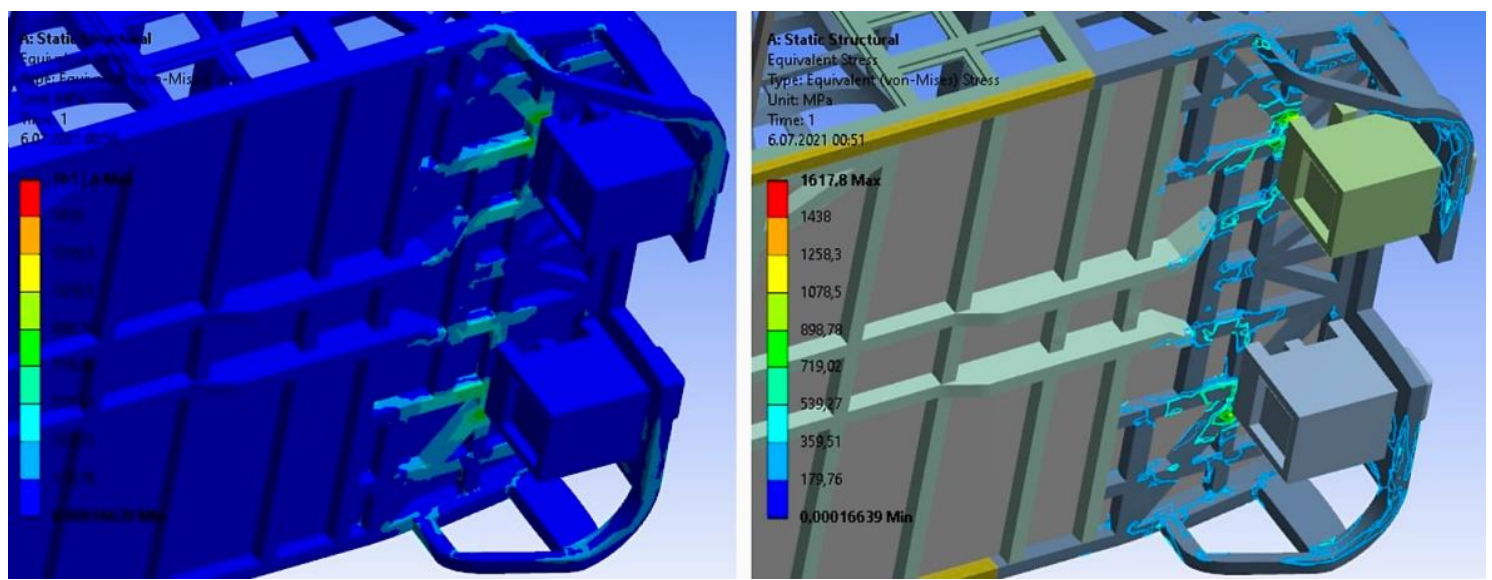

Figure 9. Von Mises stress distribution for condition-2

In this scenario, where the vehicle's equipment and body weights are analysed without a passenger load inside the vehicle, the maximum displacement in the bumper area was determined as $16 \mathrm{~mm}$. Visual data showing the amount of displacement is given in Figure 10. 


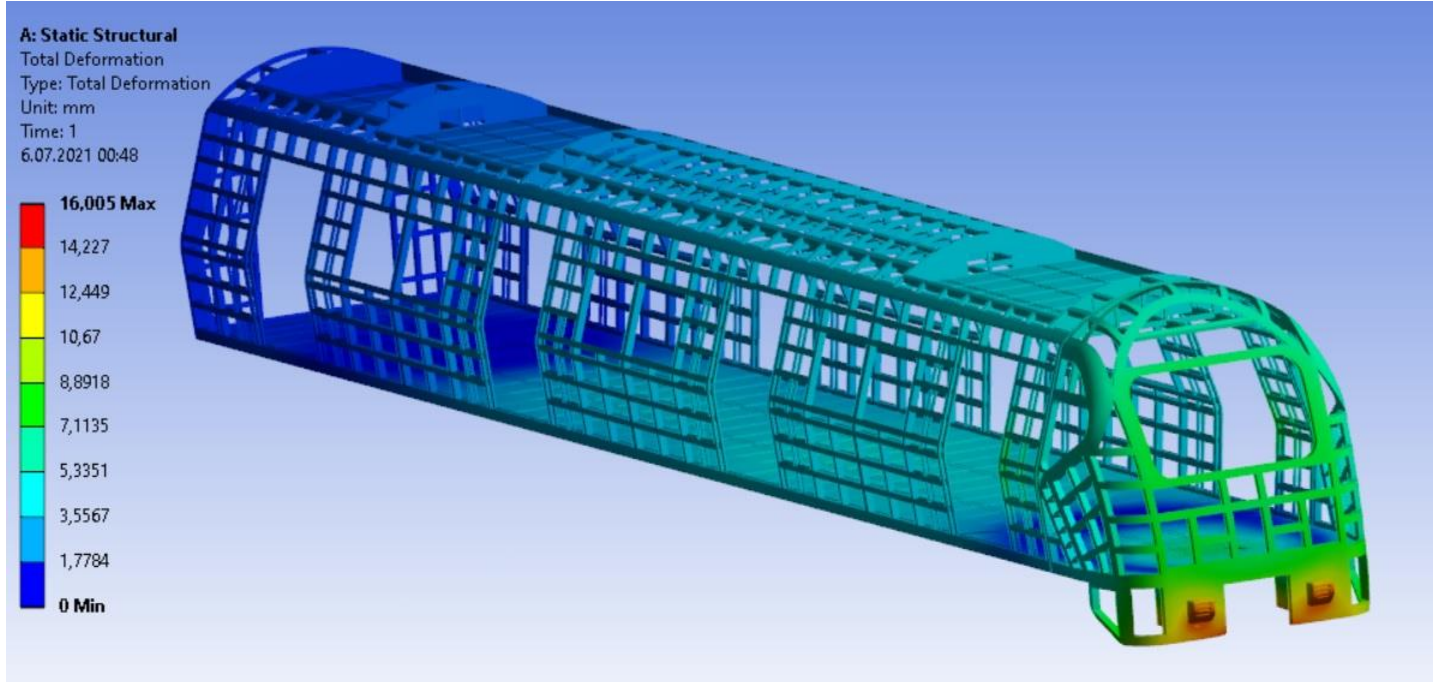

Figure 10. Maximum displacement for condition-2

\subsection{Analysis of vertical load case including compression force and passenger loads in the buffer zone (Condition 3)}

In addition to the application of $800 \mathrm{kN}$ compression force to the buffer zones of the MC vehicle, the equipment load in the vehicle body and the passenger load of 8 passengers per $\mathrm{m}^{2}$ are analysed. As a result of the static analysis, the Von Mises stress of the vertical loads in the passenger cabin areas is below the $400 \mathrm{MPa}$ yield strength of the material used in the body. However, the Von Mises stress value in the lower parts of the driver's cabin, where the bumper is mounted, is over $1500 \mathrm{MPa}$ due to the compression force in the buffer zones (Figure 11). This value is well above the yield strength, so it is not safe against the compression force in the EN 12663-1 standard from the buffer zone. This problem should be addressed by making improvements in the design of the bumper and coupling areas of the driver's cabin, as well as other relevant areas. For the bumpers to absorb the incoming impact and the resulting pressure, improvements can also be made in the design by using an in-buffer spring mechanism.
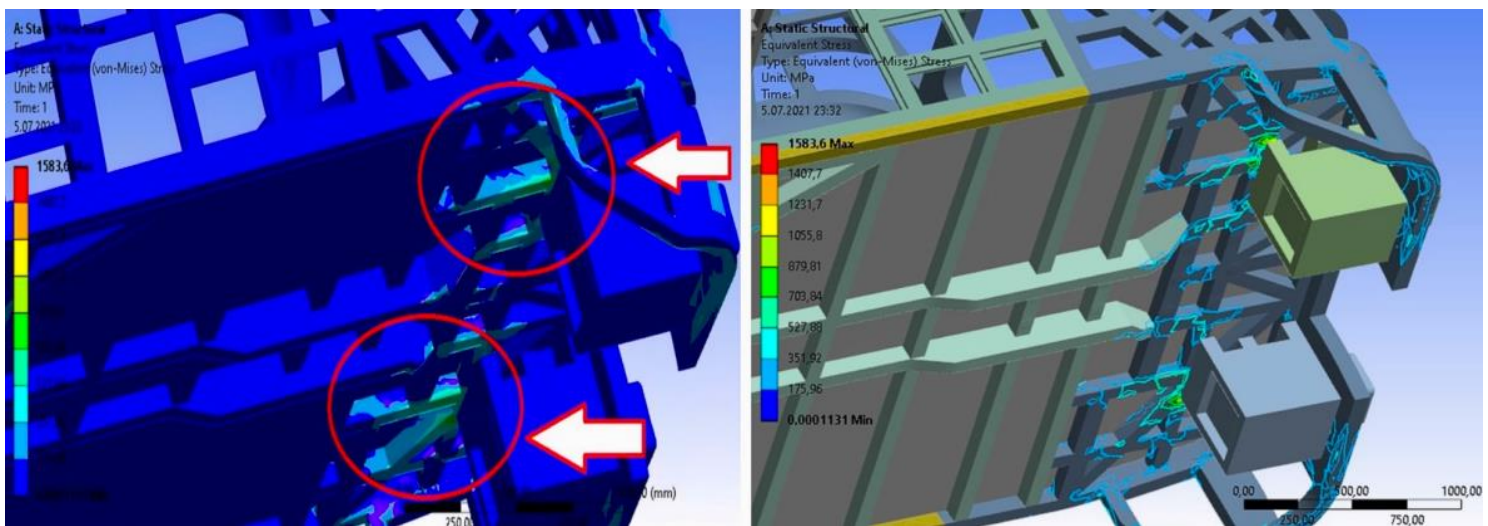

Figure 11. Von Mises stress for condition-3 driver cabin bottom

The maximum displacement when the $800 \mathrm{kN}$ compression force applied to the bumper area as well as the passenger weights are included in the finite element analysis model is shown in Figure 12. The maximum displacement is $22.117 \mathrm{~mm}$ in and around the bumper of the driver's cabin area. 


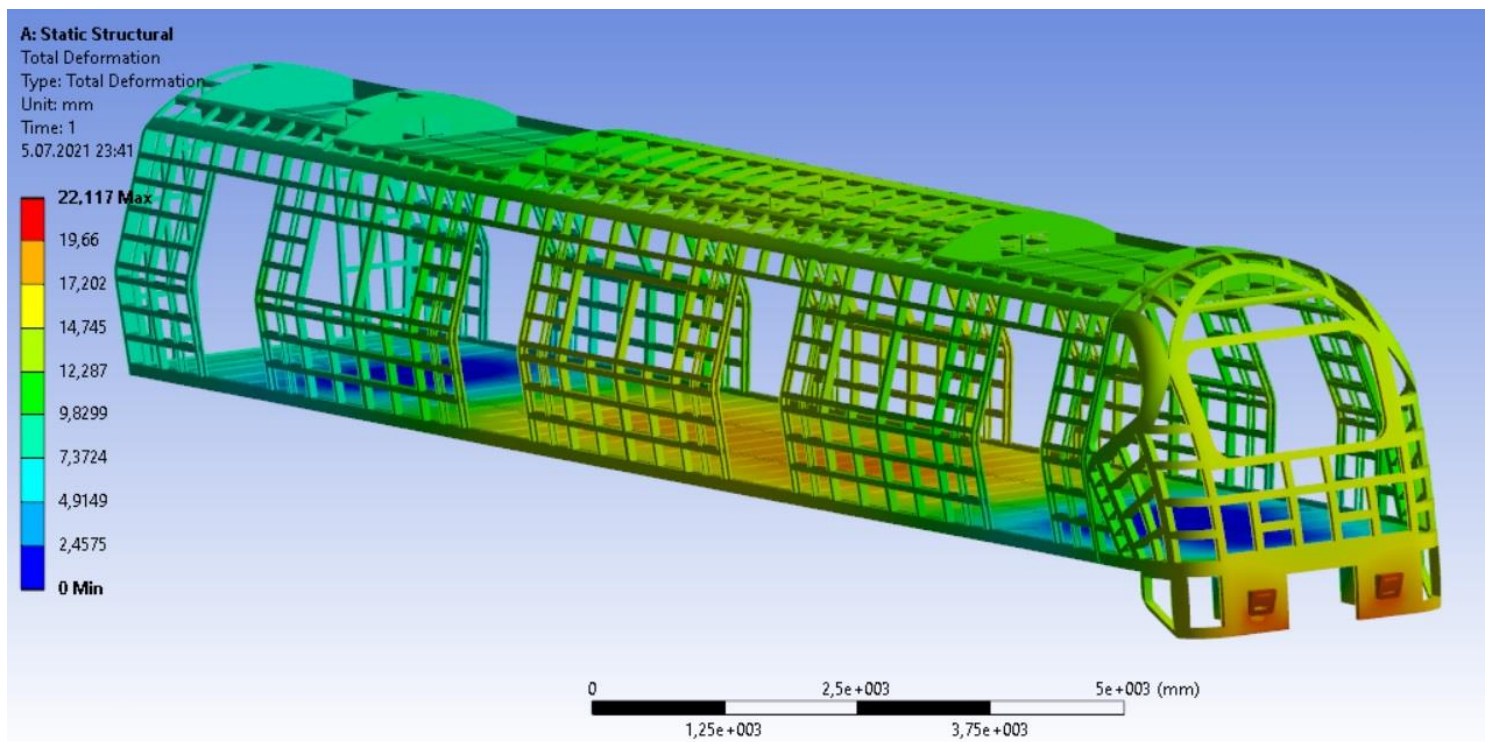

Figure 12. Maximum displacement for condition-3

\section{Conclusion and Recommendation}

In this study, a sample metro train was designed by adhering to the data obtained from literature surveys and international standards. Since metros are faster, have a higher passenger carrying capacity and are larger in size than other urban rail transportation modes, the importance of body strength is very critical. The main purpose of this study is to examine and analyze the body strength of the designed metro vehicle under the necessary loading and operating conditions. A finite element model of the MC vehicle body in the metro set, the design of which has been completed, has been created and static strength analyses have been carried out according to the loading conditions determined in EN 12663-1 standard.

It has been observed that the deformation values caused by vertical loads in the conditions of three loading situations examined are not at a level that will have a negative impact on the performance of the vehicle during operation. No stress was encountered above the safety limit of the car body in the conditions of the greatest operating load. However, when a force of 800 $\mathrm{kN}$ specified in the standard for metro vehicles was applied to the buffer zones, high regional stresses were observed around the buffer zone and at the base of the driver's cabin chassis (Condition 2 and Condition 3). The components around the bumper and in the lower sections of the driver's cabin are not safe because they remain weak against stresses, albeit regionally. Therefore, the design of the driver's cabin and bumper areas should be revised and improved. In the material used in the chassis base, a material with a higher yield strength may be preferred. In addition, no spring mechanism was used in the buffer designs and therefore no dynamic motion analysis for this region was considered within the scope of this study. If spring-loaded mechanisms are used in the bumpers, the amount of deformation can be reduced by providing damping against impacts or compression forces that may occur.

\section{References}

[1] V. R. Vuchic, Kent İçi Toplu Ulaşım ve Yaşanabilir Şehirler, vol. 1, 2 vols. İstanbul: İstanbul Ulaşım A.Ş., 2015.

[2] V. R. Vuchic, Urban Transit Systems And Technology. Hoboken, N.J: John Wiley \& Sons, 2007.

[3] E. Çekerek and M. Demir, "İstanbul Metrolarında Yolcu Konforunun Arttırılması: Sinyalizasyon Sistemi ile Otomatik Anons Kontrol Uygulaması," Demiryolu Mühendisliği Dergisi, no. 14, pp. 110121, Jul. 2021, doi: 10.47072/demiryolu.932732. 
[4] A. Damat and Z. Utlu, “İstanbul Metro İstasyonlarında İş Güvenliği Uygulamaları,” Demiryolu Mühendisliği Dergisi, no. 8, pp. 52-69, 2018.

[5] V. Arlı, Demiryolu Mühendisliği. İstanbul, 2015.

[6] V. R. Vuchic, "Urban Public Transportation Systems," Department of Systems Engineering, University of Pennsylvania, Philadelphia, PA, USA, no. 6.40.2.2.

[7] J.-S. Kim, J.-C. Jeong, and S.-J. Lee, "Numerical and experimental studies on the deformational behavior a composite train carbody of the Korean tilting train," Composite Structures, vol. 81, no. 2, pp. 168-175, Nov. 2007, doi: 10.1016/j.compstruct.2006.08.007.

[8] J.-S. Kim and J.-C. Jeong, "Natural frequency evaluation of a composite train carbody with length of 23m," Composites Science and Technology, vol. 66, no. 13, pp. 2272-2283, Oct. 2006, doi: 10.1016/j.compscitech.2005.11.036.

[9] T. Kotil, G. Yücesan, Z. Mecitoğlu, and E. Sevinçer, "Bir Hafif Metro Aracının Sonlu Elemanlar Metoduyla Statik Analizi,” İstanbul, 1998, pp. 257-265.

[10] L. Wu, S. Dong, and C. Yang, "Research on Subway Collision Animation Based on ANSYS Data," presented at the WSSE 2020: Proceedings of the 2020 The 2nd World Symposium on Software Engineering. doi: 10.1145/3425329.3425338.

[11] S. Nas, T. Kotil, G. Yücesan, Z. Mecitoğlu, and Yıllıkçı, "Boğaziçi Hafif Metro Aracının Yapısal Tasarımı," İstanbul, 1999, pp. 383-396.

[12] E. Küçükcicibıyık, S. Sabırlı, R. O. Özge, S. Vatandaş, Ö. Demir, and Z. Mecitoğlu, "Bir Raylı Taşıt Gövdesinin Sonlu Elemanlar Yöntemiyle Yapısal Analizi," Karabük, 2012, pp. 23-31.

[13] H. L. Pandül and T. Toprak, "Metro Aracı Gövde Son Montaj Tesisinin Kurulumu ve Yatırımın Finansal Değerlendirilmesi," Rolling stock final assembly facility installation and financial evaluation of the investment, vol. 19, no. 38, 2020, Accessed: May 31, 2021. [Online]. Available: http://acikerisim.ticaret.edu.tr/xmlui/handle/11467/4318

[14] "EN 12663-1 - Railway Applications - Structural Properties of Railway Vehicle Bodies."

[15] "İç ve Dış Teçhizat - EM 32000, EM 64000 Mekanik Bilgisi," TCDD.

[16] A. Aran and M. A. Temel, Paslanmaz Çelik Yassı Mamuller Üretimi Kullanımı Standartları, Acar Matbaacılık A.Ş. İstanbul, 2004.

[17] İ. Çayıroğlu, "Bilgisayar Destekli Tasarım ve Analiz (Ansys).” Karabük Üniversitesi Mühendislik Fakültesi. [Online].

Available: http://www.ibrahimcayiroglu.com/Dokumanlar/BilgisayarDestekliTasarim/BilgisayarDestekliTasari mVeAnaliz-4-hafta.pdf

[18] C. Srinivasa-Murthy, D. Wang, S. P. Beaudoin, T. Bibby, K. Holland, and T. S. Cale, "Stress distribution in chemical mechanical polishing," Thin Solid Films, vol. 308-309, pp. 533-537, Oct. 1997, doi: 10.1016/S0040-6090(97)00433-1.

[19] İ. Ovalı and C. Esen, Ansys Workbench, 2nd ed. İstanbul: KODLAB, 2017.

[20] O. Ersoy, "Bir Raylı Taşıt Gövdesinin Standartlara Göre Sonlu Elemanlar Yöntemiyle Yapısal Analizi," Yüksek Lisans Tezi, İstanbul Teknik Üniversitesi, Fen Bilimleri Enstitüsü, Makina Mühendisliği Anabilim Dalı, Katı Cisimlerin Mekaniği Programı, İstanbul, 2014. 


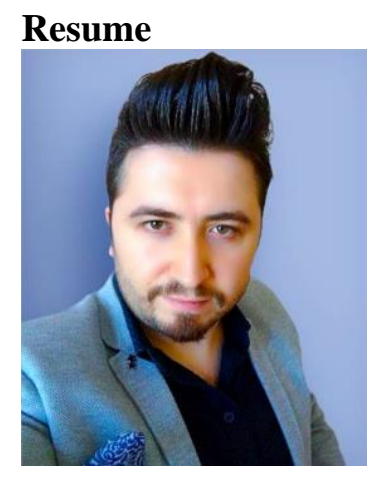

\section{Muhammed Emin ARI}

Muhammed Emin Ar1 was born in 1993. He completed his undergraduate education in Karabük, Turkey in 2018 in the Department of Mechanical Engineering, Program of Railway Systems Engineering at Karabük University. He completed his master's degree in 2021 at Karabük University, Department of Mechanical Engineering. He started his doctorate in the Department of Mechanical Engineering at Karabük University in 2021 and is still continuing his education.

E-Posta: muhammedeminari@gmail.com

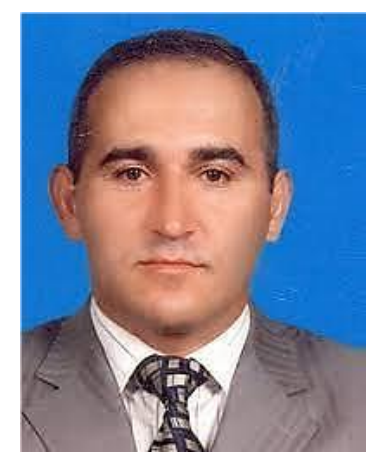

\section{İsmail ESEN}

Ismail Esen is currently an Associate Professor at Department of Mechanical Engineering of Karabük University. He got his BSc (1991), MSc (1994) and PhD Degrees (2009) from Istanbul Technical University, all in Mechanical Engineering. His research interests are rail vehicle dynamics, dynamic systems and control, robotics.

E-Posta: iesen@karabuk.edu.tr

\section{Ethics Statement:}

Authors confirm that the article is original, there is no plagiarism issue.

All authors contributed equally. 